\title{
28 The difference between zero and one
}

\author{
Voices from the Tokyo \\ anti-Olympic movements
}

\section{Sonja Ganseforth}

The scene is captured in innumerable recordings and has come to represent Tokyo - or even Japan - like no other urban view. Every few minutes, the pedestrian lights on the "scramble crossing" in one of Tokyo's busiest shopping districts turn green, dozens of cellphone cameras are raised, and hundreds of people stride across the intersection in front of Shibuya station amidst a cacophony of music and announcements from the surrounding blinking screens and mobile advertisement trucks. On a chilly February evening, a small line of seven cardboards held up above everyone's heads is making its way back and forth through this hyper-urban pandemonium, conveying a straightforward message in Japanese and English language: "2020 Tokyo No! Olympics" (see Figure 28.1).

Behind this tenacious act of protest are a dozen activists from the network No Thank You to 2020 Olympic Disasters Link, short OkotowaLink, formed in 2017. Despite turning some heads in the crowd, and with two cameramen placed in surrounding buildings to distribute the protest images on social media afterwards, anti-Olympic protest is not particularly visible in Tokyo or in Japanese media.

\section{The Games as a galvanizing moment}

Indeed, it is a leaderless group of protest veterans that has joined forces in the movement against the Games. Most of them have higher education and identify as the generation that was politicized on campuses in the 1970s, while being a little too young to have partaken in the student revolts around 1968 themselves. They work at schools, universities, publishing houses, as artists, have retired, or quit their jobs. Some have been involved in the peace movement to protect the "pacifist" Article 9 in the Japanese postwar constitution or in protest against the Japanese emperor system. Others fight for workers' rights, against gentrification and the displacement of homeless people, for the end of nuclear energy production, for the 


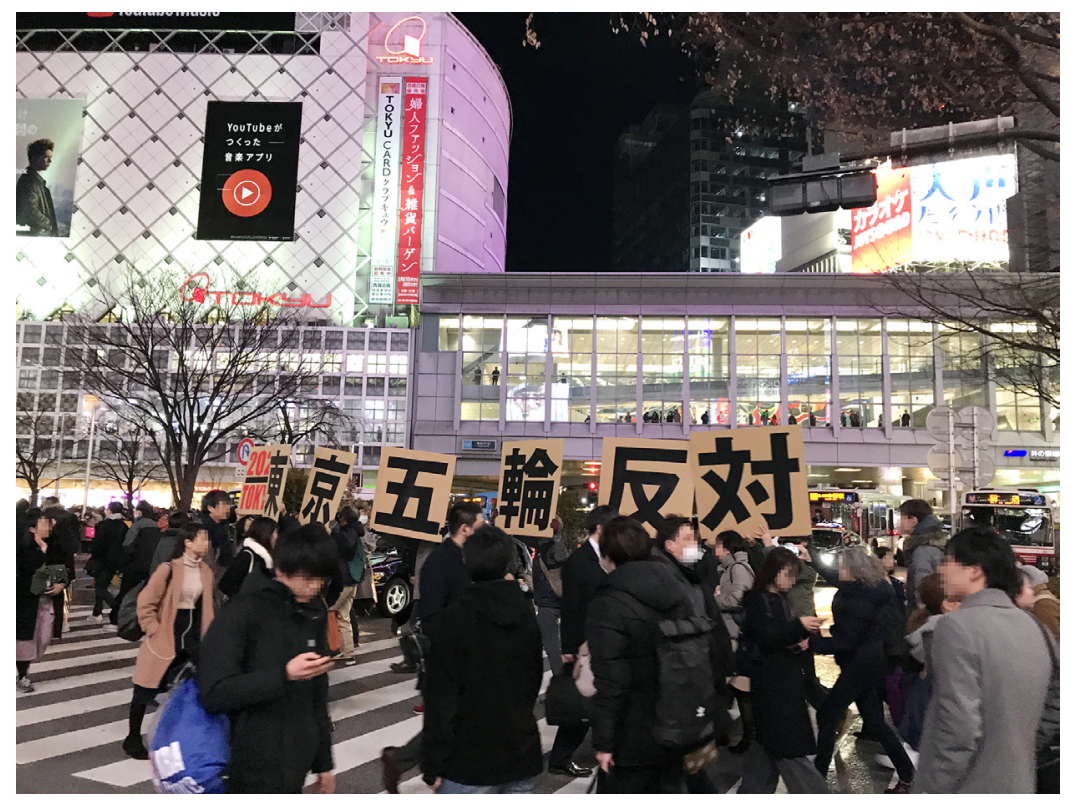

Figure 28.1 Anti-Olympic demonstration, Shibuya crossing, 2019.

Source: (C) Barbara Holthus.

rights of sexual minorities, against hyper-capitalist forms of globalization, and even for solidarity with Palestinians.

This multitude of political causes informs the members' engagement, loosely organized in thematic working groups. They hold public lectures and study group events with invited experts, publish reports of the proceedings and occasionally stage public protests such as the street performance in Shibuya. In comparison to these rather intellectual forms of protest, the affiliated group No Olympics 2020 (Hangorin no kai) is more involved in hands-on activism. With a background in defending marginalized peoples' rights, this group assembled in 2013 and has strong connections to the international anti-Olympics movement. Other groups like antinuclear movements are also cooperating, with participants joining each other's protest marches.

It is thus a rather small and close-knit intersecting community of social activists, who mostly have known each other's faces for quite some time already from various protest occasions. The Tokyo 2020 Olympics provide a galvanizing moment uniting various social movements: "Even if we knew each other, we did not really organize protest actions together. But 


\section{Sonja Ganseforth}

when the Olympics were decided upon, we had the strong feeling that people from many different issues needed to come together, because the Tokyo Olympics are bringing to light most of the many problems and contradictions in contemporary Japanese society."

\section{Olympic discontents}

Spiraling costs, budget overruns, and the exorbitant use of tax money are probably the most commonly shared criticisms of the 2020 Olympic Games in Japan and around the world. The Olympic image was further tainted by a number of scandals in the run-up to 2020, such as plagiarism of the original Tokyo 2020 logo, the scrapping of the first National Stadium design by Zaha Hadid, and, most gravely, the allegations of bribery in the bidding process.

The anti-Olympic activists raise a range of further objections, some of them concerning violations and restrictions of human rights, such as the exploitation of workers on the construction sites for the new Olympic venues. Another vulnerable group affected by the constructions for Tokyo 2020 are homeless people living in nearby parks as well as residents of public housing demolished to make way for new Olympic structures. No Olympics 2020 focuses on the fight for the rights of homeless and marginalized people. Processes of gentrification and displacement, the privatization of public space and lucrative city redevelopment have been a central concern for anti-Olympic campaigns around the world.

Securitization, increased surveillance, and further restrictions of civil liberties under the pretext of preventing terrorism at the Olympics are other aspects perturbing anti-Olympic activists. For one activist and cofounder of Attac Japan, yet another social movement group, it is clear that "Japanese capitalists are utilizing the 2011 Tohoku disasters and the Olympic Games as a Japanese shock doctrine," meaning a strategy to implement and legitimize unpopular policies such as neoliberal free market policies, privatizations, cuts in social services, or increasing surveillance in times of a state of emergency. ${ }^{1}$ The appropriation of the 2011 triple disaster in the Tohoku region in the advertisement of Tokyo's 2020 bid as "Recovery Olympics" is also a point highly criticized by protestors. They argue that the nuclear emergency is far from "under control," as proclaimed by Prime Minister Abe, and the slogan, harking back to golden postwar memories of the 1964 Olympics, is turning cynical as support for most evacuees from municipalities surrounding the wrecked nuclear power plant is discontinued. ${ }^{2}$ "Recovery Olympics is actually hindering recovery now, as money, labor, and other resources are now channeled towards the Olympics instead of Fukushima, where it still is needed," an activist 
explains. One group has made several trips to the Tohoku region to protest ongoing policies and show their solidarity: "The nuclear reactor in Fukushima was producing electricity for Tokyo; therefore, we owe it to the people in Fukushima to oppose Prime Minister Abe's Olympic plans."

With many of the activists having a background in anti-nationalist and peace movements, they also strongly reject the nationalist overtones in the race for medals and the historical roots of sports education in militarist mobilization in the tennō (emperor) system. Comparing modern Olympics to gladiator games in ancient Rome, they condemn the inhumanity and consumerism in modern sports events, and criticize the Paralympics as discriminatory for subjecting people with disabilities to the merit principle and performance measures. While the movement consents in the rejection of elite athletics, there is some disagreement on how to assess the meaning of sports for human beings in general. Some believe sports can be a joyful and liberating activity, conducive to human development and a basic right for all humans, which should be fostered through public policies. More radical objectors, however, even speak of fascism when denouncing the notion that sports are inherently good because they supposedly lead to a healthy, long life and reduce medical costs. Reminiscent of Foucauldian critiques of "biopolitics," ${ }^{3}$ they defend "the right to become sick, to live sickly, and to die early."

\section{Domestic isolation and transnational connections}

Anti-Olympic protests in Japan are not an entirely new phenomenon. They go back to the bid to host the 1988 Summer Olympics in Nagoya, when extensive local protests might very well have contributed to its failure in favor of Seoul. Before the Nagano Winter Games in 1998, however, critical voices were silenced rather drastically in favor of a "total consensus of the citizens." For Tokyo 2020, OkotowaLink activists feel the public was more critical during the bidding process, but since the positive decision in 2013, most people do not see a point in protesting anymore. Indeed, in a 2017 survey, support rates were as high as $87 \%$. A number of academic publications critically analyze the Tokyo 2020 Games, ${ }^{5}$ but the contemporary anti-Olympic movement remains rather small. OkotowaLink's monthly meetings usually have a turnout of around twenty members, while their study groups and lectures attract an average crowd of forty. One activist asserts "I think there are many people who are privately against the Olympics, but it does not become visible as a movement."

In contrast to their low visibility today, social and political movements have a considerable history in Japan. The 1950s saw strong union and strike movements, the $1960 \mathrm{~s}$ and $1970 \mathrm{~s}$ were marked by mass 


\section{Sonja Ganseforth}

mobilizations against the Security Treaty (anpo) with the United States, fierce student revolts and university campus occupations around 1968. In the aftermath of the radicalization and excessive violence of Red Army groups in Japan and even international terrorism, social activism was viewed rather suspiciously in the wider public. After an almost 40-year hiatus, however, Japan experienced a new upsurge in movement mobilizations and public protest events with anti-nuclear protests after the triple disaster of 2011. By now, the momentum seems to have died down again, at least their visibility through media coverage. Arguably, the anti-Olympic activists form part of the subaltern structures of a marginalized, yet thriving "invisible civil society" in Japan, persisting from the 1960s, which facilitated the quick organization of recent protest movements. ${ }^{6}$

In contrast to their domestic marginalization, the anti-Olympics campaigners are part of a growing global movement. "With anti-Olympic protests spreading globally, I felt it would be shameful if we did not protest a little more in Japan as well," says one veteran antimonarchist. Especially No Olympics 2020 has for some time now fostered contacts to activist groups around the world and joined the Planetary No Olympics Network. One member even went as far as Rio de Janeiro to support the local movements in 2016. Several OkotowaLink members also joined the protests at the 2018 Pyeongchang Winter Games, and conversely, visitors from other groups are expected in Tokyo in 2020, especially from future host cities Paris and Los Angeles. With international linkages growing, the greying Japanese activists are hoping for more young people to engage during or after the Olympics, particularly as they expect an economic recession after the Games. "The government wants to use the Olympics to make the inherent contradictions in Japanese society invisible, but these contradictions will come out anyways. That's when it will be very important that there are some oppositional voices, even if they are not many." The sentiment seems to be widespread among the movement, giving them a strong sense of purpose: "The difference between zero and one is what counts. That is why we will do our best to oppose and try to get as many people as possible to join in. Well, it is almost zero, like 0.01 , but it is not zero."

\section{Notes}

1 Klein, Naomi. 2007. The shock doctrine: The rise of disaster capitalism. Toronto: A.A. Knopf. See also Boykoff, Jules. 2014. Celebration capitalism and the Olympic Games. Abingdon: Routledge.

2 Koide, Hiroaki, Norma Field. 2019. "The Fukushima nuclear disaster and the Tokyo Olympics." The Asia-Pacific Journal 17, 5(3). https://apjjf.org/2019/05/ Koide-Field.html. 
3 Foucault, Michel. 2007. Security, territory, population: Lectures at the Collège de France, 1977-78. Basingstoke: Palgrave Macmillan.

4 Tajima, Atsushi. 2004. "Amoral universalism: Mediating and staging global and local in the 1998 Nagano Olympic Winter Games." Critical Studies in Media Communication 21(3): 241-260.

5 See for example: Ogasawara, Hiroki, Atsushi Yamamoto. 2019. Yappari iranai Tōkyō orinpikku [We do not need the Tokyo Olympics after all]. Iwanami Booklet 993. Tokyo: Iwanami; Nakamura, Yuji. 2018. 2020nen Tōkyō orinpikku no kenkyū: Mega supōtsu ibento no kyo to jitsu [Research on 2020 Tokyo Olympics]. Tokyo: Seibundō.

6 Steinhoff, Patricia. 2018. "The uneven path of social movements in Japan." In Chiavacci, David, Julia Obinger (eds.). Social movements and political activism in contemporary Japan: Re-emerging from invisibility. Abingdon: Routledge: $27-50$. 